\title{
Islamic Business Ethics Practice among Muslim Entrepreneurs in Kano Metropolis, Nigeria
}

\author{
Sagir Muhammad Sulaiman \\ International Institute of Islamic Banking and Finance (IIIBF), Bayero University Kano, Nigeria \\ Corresponding email: sageeerala@gmail.com \\ Aliyu Dahiru Muhammad \\ Bayero University Kano, Nigeria, Alttahir797@gmail.com \\ Tasiu Tijjani Sabiu \\ Northwest University Kano, Nigeria, ttsabiu.economics@nwu.edu.ng
}

Article History Received: June $14^{\text {th }}, 2020$ Revised: July $17^{\text {th }}, 2020$ Accepted: July $25^{\text {th }}, 2020$

\section{Abstract}

There are persistent increasing number of scenarios in Singer and Dawanau markets of Kano metropolis which are seen as unethical among which includes deception, inappropriate weight and measures, hoarding and price manipulation as well as false-swearing to support a sale. This study therefore assesses the determinants of Islamic business ethics practices among Muslim entrepreneurs in Kano metropolis, Nigeria. Structural Equation Modelling (SEM) technique is employed in analysing the hypothesized model of the study. The results indicate that entrepreneurs fairly adhere to Islamic business ethics practice while legal and organizational factors significantly affect Islamic business ethics, but Individual factors do not. The study recommends the need for Kano State Ministry of Commerce and Industry in collaboration with market organizational leaders to engage in public enlightenment on the importance of business as an act of worship (Ibadat). It was suggested that organization leaders i.e. Market leaders (trade union leaders) should liaise with Kano state Shariah Commission to set standard for Islamic business ethics whereas Hisbah Board to enforce compliance. The study further suggests that the concept of ethics should be incorporated in teaching and learning curriculum.

Keywords: Islamic business ethics, Legal factors, Organizational Factor, Individual factor, structural equation modelling.

JEL Classification: C31; M19; Z12

@ IJIEF 2020 published by Universitas Muhammadiyah Yogyakarta, Indonesia All rights reserved

DOI:

https://doi.org/10.18196/ijief.3233
Web:

https://journal.umy.ac.id/index.php/ijief/article/view/9033

Citation:

Sulaiman, S. M., Muhammad, A. D., \& Sabiu, T. T. (2020) Islamic business ethics practice among Muslim entrepreneurs in Kano Metropolis, Nigeria. International Journal of Islamic Economics and Finance (IJIEF), 3(2), 33-62. DOI: https://doi.org/10.18196/ijief.3233.

\section{Introduction}


Sulaiman \& Muhammad | Islamic Business Ethics Practice among Muslim Entrepreneurs in Kano Metropolis, Nigeria

\subsection{Background}

Muslim business entrepreneurs should possess unique standard qualities distinct from non-Muslim business entrepreneurs. Muslim business entrepreneurs are obliged to have faith in the oneness of Allah and nothing worthy of worship except Allah (Ismail, 2006). This Tawheedic approach in Islam is the ultimate guiding principle of entrepreneurship. Ethics in Islamic context is view in two different categories; in the first stage ethics toward the oneness of the creator Allah, a Muslim should worship Allah and believe in his oneness, secondly a person should be ethically sound toward others in term of maintaining good relationship i.e. as a brother or sister keeper.

The character of Prophet Muhammad (PBUH) is a good example in which if implemented by business entrepreneurs would discourage self-serving and individualistic tendencies (Beekun, 2012).

Dawanau and Singer Markets are located in Kano state of Nigeria which are predominantly occupied by Muslim entrepreneurs (Abdu, 2018; Umar, 2018). Most of the entrepreneurs in these markets share different things in common among which is selling and buying of consumable goods. while Dawanau is an International market for solely grains, entrepreneurs in Singer market specialized in buying and selling of foods stuffs and soft drinks. Burji (2018) remark that unethical business practices such as selling of expired commodities, selling low quality standard goods in the name of high standard or generally selling out goods with already known defects without the consent of buyers and inappropriate weight and measures among others are rampant in both Singer and Dawanau markets of Kano state.

Therefore, it is pertinent to assess if Muslims entrepreneurs in these markets adheres to Islamic business ethics in carrying out day to day business activities. It is appealing to know the extent to which Muslim entrepreneurs in these Market either engages or otherwise in unethical practices such as deception, inappropriate weight and measures, hoarding, fraud, deliberate purchase of stolen goods, false-swearing to support a sale, middleman ship and usurious practices. It is in the light of the foregoing that this study assesses the determinant of Islamic business ethics among entrepreneurs in Kano metropolis with a view to determining how entrepreneurial activities can be made to conform to the teaching of the sharia'ah and enhance the Islamic moral uprightness of the entrepreneurs for enhanced Allah's blessings.

The justification for selecting Kano as area of interest is due to the facts that: it's a Muslims majority state accounting for $99 \%$ of the indigenous population. Secondly it's a Shariah compliant State with the presence of 
Sulaiman \& Muhammad | Islamic Business Ethics Practice among Muslim Entrepreneurs in Kano Metropolis, Nigeria

institutions like Shariah Commission and Hisbah Board among others. Thirdly Kano state is the second largest commercial state in Nigeria.

Most of the researches on Islamic business ethics are conceptual rather than empirical studies. Empirical work in this context are largely conducted in Muslims countries such as Malaysia, Syria, Indonesia and Bangladesh. Equally, some are carried out in sub Saharan African countries such as Ghana. Due to the fact that some of these countries share common socioreligious but different economic values with Nigeria and Kano State in particular, hence, the need to replicate the study in Nigerian context. Moreover, the literature in this area focus on formal sectors i.e. Islamic financial institution (Husin \& kerain 2019; Nizam, Binti, Safizal \& Osman, 2015; Imam, Sattar \& Muneer 2013). However, studies with the focus in informal sectors i.e. market places are rare. Yeboah-Assiamah (2014) represent the first attempt in investigating Islamic business ethics in market place. The study employed one-on-one in-depth interview to (12) Muslims women traders, (5) regular customers of the traders and (2) Muslim religious leaders in Kumasi Central market, Ghana. This raises the need to carry similar study in Nigerian context using different methodological approach i.e. structural equation modelling. In this regard this study gives both empirical and methodological contribution

\subsection{Objective}

The aim of this study is to assess the application of Islamic business ethics by Muslim entrepreneurs in Dawanau and Singer Markets. The specific objectives of the study are; (i) to assess whether legal factors have significant effect on Islamic business ethics in Dawanau and Singer Markets. (ii) to examine whether organizational factors have significant effect on Islamic business ethics in Dawanau and Singer Market; and (iii) to explore whether individual factors have significant effect on Islamic business ethics in Dawanau and Singer Markets.

This paper comprises of five sections. Section one is introduction, Section two dwells on both empirical and theoretical literatures. Section three focuses on methodology. Section four consists of data presentation and analysis. Lastly section five is the conclusion, recommendation and frontier for further studies.

\section{Literature Review}


Sulaiman \& Muhammad | Islamic Business Ethics Practice among Muslim Entrepreneurs in Kano Metropolis, Nigeria

\subsection{Background Theory}

The theoretical framework employed in this study is Divine command theory using Tauhidiq paradigm approach which source its origin from both primary and secondary Islamic sources of knowledge. Divine Command Theory opined that what should be good or bad, permitted or prohibited is subjected to religion belief, this theory signifies that what is right or wrong is determine by God. In other words, ethics and religion always go together (Rachels \& Rachels, 1993). Religious people commonly believe that ethics can be understood only in the context of religion i.e. Jewish and Christian religions. According to Rachels and Rachels (1993) God is seen as a lawgiver who has created the universe and all other things. According to Mohammed (2005) In contrast to Jewish and Christian religions, Islam reveals the sole purpose of existence of humankind in this world clearly as worshipping the One God through the engagement in good things and avoidance from engaging in wrong things. Tauhidiq paradigm is an Islamic approach to divine command theory that focus on Tauhid (unity of Allah) or the Islamic monotheism that provides harmonious linkages between the worldly affairs (Al'Dunya) and the Hereafter (Al'Akhirah) in the context of business processes, actions and decisions (Rahman, 1995; Hamid, 1999). Tauhidiq paradigm approach of divine command theory is adopted and serve as a basis for assessing the determinants of the application of Islamic Business ethics among entrepreneurs in Kano metropolis Nigeria.

\subsection{Previous Studies}

There is scanty empirical literature on Islamic business ethics, this is evident in the work of Husin and kerain (2019), Nizam et al., (2015), YeboahAssiamah (2014), Manan, Kamaluddin and Puteh Salin (2013) as well as Imam, Sattar and Muneer (2013). Given limited empirical literature this study contributes to the literature on Islamic business ethics practice specifically in market place. In addition, most of the study empirically tested Islamic ethics model in works places using either individual or organizational factors as determinants of Islamic ethics. This study therefore incorporates three determinants of Islamic ethics as conceptually suggested by Beekun (1996) that include individual, organizational and legal factors. The scanty literatures are hereby discussed below.

Husin and Kernain (2019) conducted an empirical assessment of the influences of individual behaviour and organizational commitment towards the enhancement of Islamic Work Ethics (IWE) at the Royal Malaysian Air Force and the data was analyzed using both descriptive analyses and Structural Equation Modelling (SEM) to conduct confirmatory factor analysis only and the findings reveals that both individual behaviour and 
organizational commitment have significantly correlated with the enhancement of IWE. Meanwhile, same variables can be further empirically tested in another case study.

Nizam et al, (2015) identify Islamic work ethics as a concept of ethics that is based on Islamic teaching and principle which rely on faith. A structural model was constructed to test the effects of Islamic work ethics on organizational commitment. 156 respondents from randomly selected (SMEs) were given six-point Likert scale questionnaire. The study found that the structural model is acceptable in term of validity and reliability thus can be used to measure the relationship between two variables. The study also found that Islamic work ethics affects organizational commitment and its three dimensions; affective, normative and continuance commitment. However, there is need to consider the effect of other exogenous variables among which are (economic, political and social).

Yeboah-Assiamah (2014) analyses Muslim women traders understanding of Islamic business ethics in Kumasi central market Ghana, one-on-one in-depth interview was conducted and purposive sampling technique was adopted to select 19 respondents consist of (12) Islam women traders, (5) regular customers of the traders and (2) Muslim religious leaders, The study found out that the main teachings of Islam to traders include Sincerity, honesty, humility, fairness in pricing, truthfulness, love for customers and fellow traders. The study concludes that Islamic women traders in the Kumasi Central market do have fair understanding of Islamic work ethics; further studies should assess the impact of knowledge of these ethical principles on the trading behaviours of Islamic women traders in the Kumasi central market using quantitative approach.

Manan et al., (2013) examine the influence of organizational commitment on Islamic work ethics among employee of Banking Institutions in Malaysia, study employs a survey method whereby primary data is collected via a distribution of questionnaires, simple random sampling is used to draw a total of 500 samples and a spearman correlation was used to test for the relationship between variables of the study. The findings of this study indicate that all Islamic work ethics (IWE) variables namely, effort, teamwork, honesty and accountability are positively and significantly related to organizational commitment, similar studies can be carry out in informal sector i.e. market places by employing a robust technique of analysis i.e. SEM multivariate technique.

Imam et al., (2013) examine the relationship between Islamic work ethics (IWE), mediating role of Manager bad personality i.e. personality $X$, manager good personality i.e. personality $Y$, and employee performance, 400 questionnaires through simple random sampling technique was distributed 
Sulaiman \& Muhammad | Islamic Business Ethics Practice among Muslim Entrepreneurs in Kano Metropolis, Nigeria

to PhD faculty members of universities of Pakistan, the structural equation modelling (SEM) was performed using SPSS 19 and AMOS 19.0. and the result revealed that Islamic work ethics can improve the performance of employees with various personalities, i.e. either by personality $X$ or personality $Y$, it is important to mention that this model is significant and provides empirically and theoretically consistent findings, researchers also need to realize that the external environment (economic, political, social and technological) also affects the performance of an organization and employees. Therefore, there is need to consider environmental factor as moderating variable.

Based on the literature review, the conceptual framework was developed to support this study, and it is presented in figure 1.

\subsection{Conceptual Framework}

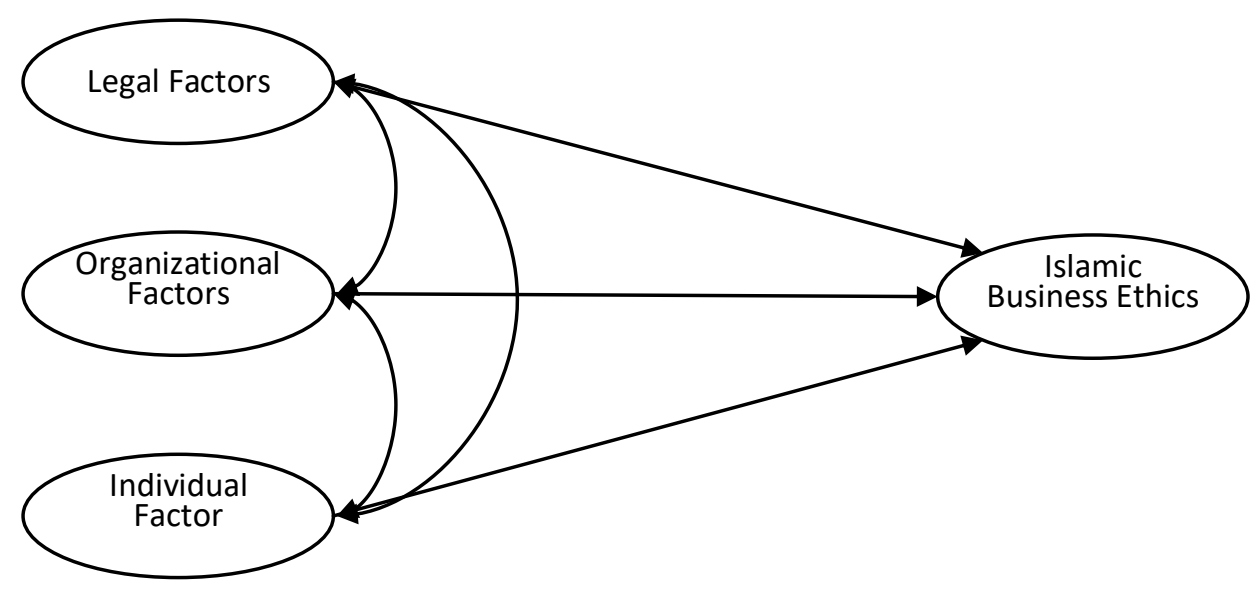

Source: Adopted from Beekun (1966).

Figure 1. Research Framework.

Figure 1 shows that all the four variables are in oval shape which signifies that, they are all lantern construct/variables, whereas Islamic business ethics is the endogenous variable, the exogenous variables of the study are legal factors, organizational factors and individual factors which are also the determinant of Islamic business ethics practice.

\section{METHODOLOGY}


Sulaiman \& Muhammad | Islamic Business Ethics Practice among Muslim Entrepreneurs in Kano Metropolis, Nigeria

The aim of this study is to assess the influence of legal factors, organizational factors and individual factors on application of Islamic business ethics by Muslim entrepreneurs in Dawanau and Singer Markets of Kano metropolis, Nigeria.

\subsection{Data}

The study uses cross-sectional survey design. The number of entrepreneurs in Singer Market comprises of 25,355 registered and 35,000 unregistered, this constitutes the population of entrepreneurs in Singer to be 60,355 (Yakasai, 2018). on the other hand, the number of registered entrepreneurs in Dawanau market is 26,850 while the estimated unregistered amount to 3,610 , this constitutes the population of business entrepreneurs in Dawanau market to be 30,460 (FAMIS, 2017). Therefore, the total population of the study areas is 90,815. the study used Bertlett, Kottrlik and Higgins (2001) sample size formula as adopted in Mensah (2016) and arrived at 383 sample size, but for the purpose of this study; 400 respondents would be questioned so as to improve the response rate and also to reduce the sampling error. The use of self-administered questionnaire is adopted. In this study, aside the demographic attributes or variables, which were obtained at the nominal scale all other variables, were in ordinal and interval scaling using the Likertscale. The original Rensis Likert was maintained in this study by using fivepoint Likert-scale format. purposive sampling technique is adopted to capture the target respondents and distribution of questionnaires is proportionally based on the target population in each of the selected case study namely Singer and Dawanau Markets.

Table I. Summary of Sample Size Proportion Distribution

\begin{tabular}{lcc}
\hline Market & Sample Frame & Proportion of sample size \\
\hline Singer & 26,850 & $205.727 \approx 206$ \\
Dawanau & 25,355 & $194.273 \approx 194$ \\
Total & 52,205 & 400 \\
\hline
\end{tabular}

Source: FAMIS (2017) and Yakasai (2018) and Computed by author.

\subsection{Model Development}


Sulaiman \& Muhammad | Islamic Business Ethics Practice among Muslim Entrepreneurs in Kano Metropolis, Nigeria

The following models are used in explaining the relationships between (Legal factors, Organizational factors and Individual factors) and Islamic business ethics construct.

Three independent variables (legal factors, organizational factors and individual factors) are adopted from previous conceptual studies such as Beekun, (1996) Ahmad, (2009) Ngurah, Kaderi, Sufiati and Toha, (2014) as well as Iqbal and Islam, (2015).

Islamic business ethics: this is endogenous variable which is defined as overall ethical behaviour of individuals in a business. It is measured by seven measurements instruments or dimensions namely; God fearing (Taqwa), trust, justice, equity, benevolence, sincerity and responsibility. The questions are based on these seven dimensions or measurements. It is based on these seven items that questions are raised.

Legal factors: this is exogenous variable defined as Shariah and figh rulings in business transaction and is measured by seven dimensions namely mutual agreement between parties involved, both parties must be qualified to engage in transactions, ownership of goods being traded, permissibility of goods, dispensability, absence of anonymity as well as forbidden of bribery. It is based on these seven items that questions are raised.

Organizational factors: as exogenous variable in this study signifies degree of commitment of organization's leaders to ethical conduct. This construct is measured based on six dimensions namely, code of ethics among entrepreneurs, code of ethics between entrepreneurs and customers, code of ethics between entrepreneurs and suppliers/distributors, code of ethics between entrepreneurs and employees, code of ethics between entrepreneurs and community and lastly code of ethics that establish a body that is in-charge of supervising and ensuring ethical conduct among entrepreneurs and other stakeholders for example Al-hisbah. It is based on these six items that questions are raised.

Individual factor: as exogenous variable is as seen the specific factors that may affect individual attitude which measured using seven dimensions that consist of stages of moral development, personal values, family influences, peer influences, life experiences, situational factors and culture. It is based on these seven items that questions are raised.

The functional relationship of the model is given

i3)

The multi-variate form of the regression model is given by 
Sulaiman \& Muhammad | Islamic Business Ethics Practice among Muslim Entrepreneurs in Kano Metropolis, Nigeria

$i$

$I B F_{i}=$ Islamic Business Ethics variable at a given point in time .

$L F_{i}=$ Legal Factor at a given point in time

${ }_{i}=$ Organizational Factor at a given point in time

$I F_{i}=$ Individual Factor at a given point in time.

$\varpi_{\circ}=$ Intercepts/ autonomous variable.

$1, \varpi_{2}$ and $\varpi_{3}=$ are parameter estimates or coefficients of independent constructs, it depicts the degree of Islamic business ethics by applying the independent constructs (LF, OF and IF).

$i=$ the error term or the amount which account for other possible factors that could influence $Y_{i}$ that are not captured in the model.

2 and $\varpi_{3}>0$.

\subsection{Method}

Data analysis for this study employed the Structural Equation Modelling (SEM) technique using the Maximum Likelihood Estimation (MLE) (Chin 1998; Gefen, Straub \& Boudreau, 2000). Structural Equation Modelling (SEM) is a robust statistical data analysis technique that is used for multivariate analysis with latent variables. SEM is a set of linear equations for testing the hypothesis about the relationship between observed and latent variables and uses a confirmatory approach (Hair et al., 2006; Emmoglu, 2011). Observed variables are indicators of the constructs in the questionnaires and latent or unobserved variables are constructs in the theoretical model. This technique is used because the researcher is trying to examine the impact of certain exogenous constructs (Legal factor, Organizational factor and Individual factor) on another endogenous construct: Islamic Business Ethics. The data was analysed using the Statistical Package for Social Sciences (SPSS) software, version 22.0 and AMOS software version 21.

\section{Result and Analysis}

\subsection{Descriptive Analysis}

International Journal of Islamic Economics and Finance (IJIEF), 3(2), SI, 33-62 |41 
Sulaiman \& Muhammad | Islamic Business Ethics Practice among Muslim Entrepreneurs in Kano Metropolis, Nigeria

The descriptive analysis section begins with the demographic features of the respondents. The survey questionnaire requires respondents to answer five demographic questions reflecting their gender, age group, level of education, number of years being in Business, and Registration with Market Association.

In terms of gender, Table 2 revealed that 386 (97\%) of the subjects are males while only11 (3\%) are females. The justification for presence of high number of male respondents across the markets is due to religious and cultural norms. Accordingly, 191 (48\%) of the respondents fall under 18-29 age group, while 30-59 age bracket consist of 159 (40\%) of the respondents whereas $47(12 \%)$ falls within the age group of 60 -Above. This signifies that majority of the respondents are young entrepreneurs within the age bracket of 18-29 and then follow by 30-59 age group.

Table 2. Respondents Profile

\begin{tabular}{|c|c|c|c|c|}
\hline \multicolumn{5}{|c|}{ Gender } \\
\hline & Frequency & Percent & Valid percent & Cumulative percent \\
\hline Female & 11 & 2.8 & 2.8 & 2.8 \\
\hline Male & 386 & 97.2 & 97.2 & 100.0 \\
\hline Total & 397 & 100.0 & 100.0 & \\
\hline \multicolumn{5}{|c|}{ Age } \\
\hline $18-29$ & 191 & 48.1 & 48.1 & 48.1 \\
\hline $30-59$ & 159 & 40.1 & 40.1 & 88.2 \\
\hline 60-Above & 47 & 11.8 & 11.8 & 100.0 \\
\hline Total & 397 & 100.0 & 100.0 & \\
\hline \multicolumn{5}{|c|}{ Education } \\
\hline Primary & 172 & 43.3 & 43.3 & 43.3 \\
\hline Secondary & 52 & 13.1 & 13.1 & 56.4 \\
\hline Tertiary & 17 & 4.3 & 4.3 & 60.7 \\
\hline Others & 156 & 39.3 & 39.3 & 100.0 \\
\hline Total & 397 & 100.0 & 100.0 & \\
\hline \multicolumn{5}{|c|}{ Years in Business } \\
\hline $0-5$ & 133 & 33.5 & 33.5 & 33.5 \\
\hline $6-10$ & 195 & 49.1 & 49.1 & 82.6 \\
\hline $11-15$ & 59 & 14.9 & 14.9 & 97.5 \\
\hline 16-Above & 10 & 2.5 & 2.5 & 100.0 \\
\hline Total & 397 & 100.0 & 100.0 & \\
\hline \multicolumn{5}{|c|}{ Registration with Market Association } \\
\hline No & 8 & 2.0 & 2.0 & 2.0 \\
\hline Yes & 389 & 98.0 & 98.0 & 100.0 \\
\hline Total & 397 & 100.0 & 100.0 & \\
\hline
\end{tabular}

Source: Computed from field Survey Data (2018).

Table 2 also reveals that 172 (43\%) of the respondents obtained primary certificate, while 52 (13\%) of the respondents held secondary certificate, whereas $17(4 \%)$ of the subjects obtained tertiary certificate but 156 (39\%) of the respondents obtained other certificates. This clearly shows that majority 
Sulaiman \& Muhammad | Islamic Business Ethics Practice among Muslim Entrepreneurs in Kano Metropolis, Nigeria

of the subjects obtained the minimum of primary certificate and follows by others i.e. Islamiyya school, but few respondents obtained secondary and tertiary certificates with $13 \%$ and $4 \%$ respectively.

Table II further reveals that $133(33 \%)$ of the respondents had 0-5 years in the business, while 195(49\%) of the subject had 6-10 years in business, while $59(15 \%)$ of the subjects acquired $11-15$ years in business and only $10(3 \%)$ of the respondents spent 16-Above years. It is also indicated that 389 (98\%) of the respondents registered with market association while only $8(2 \%)$ of the subjects do not registered with the market association.

\subsection{Result of Exploratory Factor Analysis}

In this section, discussions on the results of the Exploratory Factor Analysis (EFA) are outlined below.

Table 3. KMO and Bartlett's Test

\begin{tabular}{|c|c|c|}
\hline \multicolumn{3}{|c|}{ Islamic business ethics } \\
\hline \multicolumn{2}{|c|}{ Kaiser-Meyer-Olkin Measure of Sampling Adequacy } & 0.855 \\
\hline \multirow[t]{3}{*}{ Bartlett's Test of Sphericity } & Approx.Chi-Square & 4727.249 \\
\hline & Df & 21 \\
\hline & Sig & 0.000 \\
\hline & Legal Factor & \\
\hline \multicolumn{2}{|c|}{ Kaiser-Meyer-Olkin Measure of Sampling Adequacy } & 0.909 \\
\hline \multirow[t]{3}{*}{ Bartlett's Test of Sphericity } & Approx.Chi-Square & 5090.952 \\
\hline & Df & 21 \\
\hline & Sig & 0.000 \\
\hline \multicolumn{3}{|c|}{ Organization Factor } \\
\hline \multicolumn{2}{|c|}{ Kaiser-Meyer-Olkin Measure of Sampling Adequacy } & 0.891 \\
\hline \multirow[t]{3}{*}{ Bartlett's Test of Sphericity } & Approx.Chi-Square & 3200.246 \\
\hline & Df & 15 \\
\hline & Sig & 0.000 \\
\hline \multicolumn{3}{|c|}{ Individual Factor } \\
\hline \multicolumn{2}{|c|}{ Kaiser-Meyer-Olkin Measure of Sampling Adequacy } & 0.921 \\
\hline \multirow[t]{3}{*}{ Bartlett's Test of Sphericity } & Approx.Chi-Square & 4078.217 \\
\hline & Df & 21 \\
\hline & Sig & 0.000 \\
\hline
\end{tabular}

Source: Computed from field Survey Data (2018).

From Table 3, the results of Islamic business ethics Exploratory Factor Analysis (EFA) show a high value of 0.855 for the Kaiser-Meyer-Olkin Measure (KMO) and the significance of the Bartlett's test of sphericity tests (X2: 4727.249, DF: 21, Sig.: 0.000), the legal factors Bartlett's Test of Sphericity was significant (Chi square $=5090.952, p$-value $<0.000$ ). The 
Sulaiman \& Muhammad | Islamic Business Ethics Practice among Muslim Entrepreneurs in Kano Metropolis, Nigeria

measure of sampling adequacy by Kaiser-Meyer-Olkin, (KMO) is 0.909, in case of the organizational factors KMO value of 0.891 is good as it exceeds the recommended value of 0.6 and the Bartlett's Test significance value is (Chi-square $=3200.246$, $p$-value $<0.000$ ), the individual factors results indicate that the Bartlett's Test of Sphercity was significant (Chi-square =4078.217, p-value $<0.000$ ). The measure of sampling adequacy by KMO is 0.921 , thus, this indicate the suitability of the research data for structure detection Hair, Black, Babin, Anderson \& Tatham (2006). This is confirmed by the KMO values close to 1.0 and the significance value Bartlett's Tests close to 0.000 , hence this indicate that the data at hand is adequate to proceed into confirmatory factor Analysis (Hair et al, 2006; Zainudin, 2014).

\subsection{Result of Confirmatory Factor Analysis}

The main objective of this study is to utilise Structural Equation Modelling (SEM) to examine the effect of the legal factors, organizational factors and individual factors on Islamic business ethics practice. Before proceeding with the SEM analysis, the exploratory data analysis was conducted to ensure that the data fulfilled the requirements for SEM analysis. The tested measurement model is presented in Figure 2.

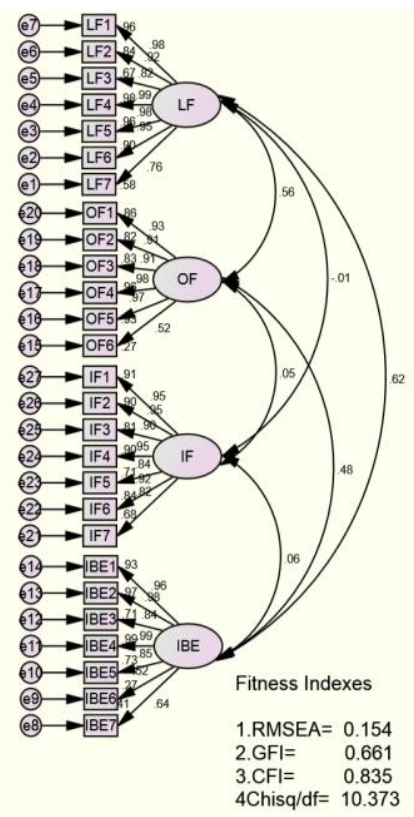

Source: Field Survey Data (2018) and Computed using Amos 22.

Figure 2. Confirmatory Factor Analyses (Measurement Model).

Table 4. Items Description and Items Deletion

\begin{tabular}{ccc}
\hline Item Label & Factor Loading & $\mathrm{R}^{2}$ \\
IBE1 & 0.96 & 0.93 \\
\hline
\end{tabular}


Sulaiman \& Muhammad | Islamic Business Ethics Practice among Muslim Entrepreneurs in Kano Metropolis, Nigeria

\begin{tabular}{|c|c|c|}
\hline IBE2 & 0.98 & 0.97 \\
\hline IBE3 & 0.84 & 0.71 \\
\hline IBE4 & 0.99 & 0.99 \\
\hline IBE5 & 0.85 & 0.73 \\
\hline IBE6 & 0.52 & 0.27 \\
\hline IBE7 & 0.64 & 0.41 \\
\hline LF1 & 0.98 & 0.96 \\
\hline LF2 & 0.92 & 0.84 \\
\hline LF3 & 0.82 & 0.67 \\
\hline LF4 & 0.99 & 0.98 \\
\hline LF5 & 0.89 & 0.96 \\
\hline LF6 & 0.95 & 0.90 \\
\hline LF7 & 0.76 & 0.58 \\
\hline OF1 & 0.93 & 0.86 \\
\hline OF2 & 0.91 & 0.82 \\
\hline OF3 & 0.91 & 0.83 \\
\hline OF4 & 0.98 & 0.96 \\
\hline OF5 & 0.97 & 0.93 \\
\hline OF6 & 0.52 & 0.27 \\
\hline IF1 & 0.95 & 0.91 \\
\hline IF2 & 0.95 & 0.90 \\
\hline IF3 & 0.90 & 0.81 \\
\hline IF4 & 0.95 & 0.90 \\
\hline IF5 & 0.84 & 0.71 \\
\hline IF6 & 0.92 & 0.84 \\
\hline IF7 & 0.82 & 0.68 \\
\hline
\end{tabular}

Source: Computed from field Survey Data (2018).

The confirmatory factor analyses (CFA) results in Table IV and figure II shows the four constructs consisting of legal factors, organizational factors, individual factors and Islamic business ethics show that the factor loading for each item together with its $R^{2}$. All of the factor loading are above the recommended value of 0.60, except IBE6 with a value of 0.52 and OF6 with a value of 0.52 which all need to be deleted before proceeding to the next analysis i.e. structural modelling.

The CFA result confirms that the model was not fit and ready for further analysis. The values indicate that all the fitness indexes i.e. (RMSEA, GFI, CFI and Chisq/df) for the constructs do not achieve the required level and the proposed model does not adequately fit the data. In general, the result of the assessment of the measurement model did not show a solid evidence of 
Sulaiman \& Muhammad | Islamic Business Ethics Practice among Muslim Entrepreneurs in Kano Metropolis, Nigeria

unidimensionality, convergent validity, and discriminant validity. Therefore, to achieve the fitness indexes of the measurement model, a modification need to be carried out in the model where any factor loading with less than 0.60 will be deleted. The new modified model is presented in figure 3 below.

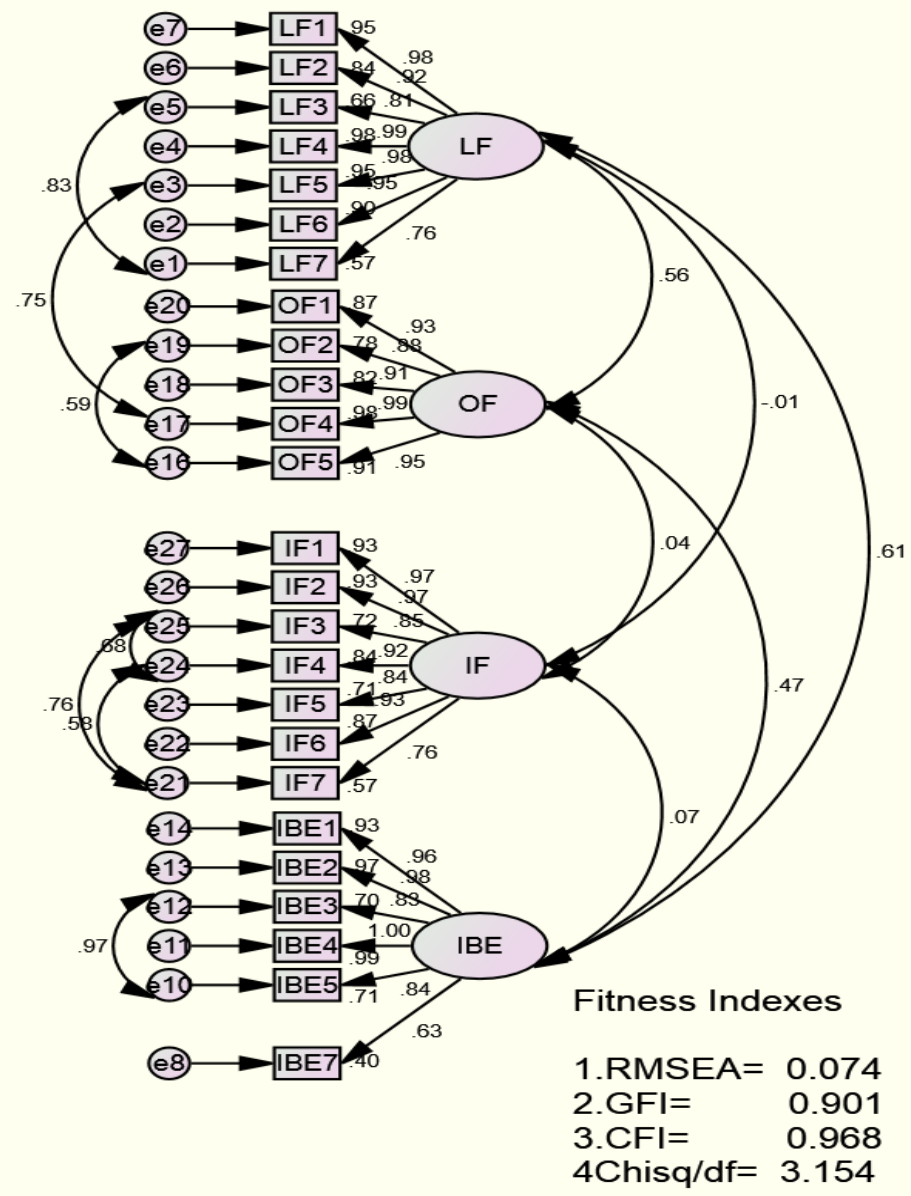

Source: Field Survey Data (2018) and Computed using Amos 22.

Figure 3. The New Factor Loading after two items with low factor loading were deleted (The New Measurement Model).

Table 5. Items Description after deletion

\begin{tabular}{ccc}
\hline Item Label & Factor Loading & $\mathrm{R}^{2}$ \\
IBE1 & 0.96 & 0.93 \\
IBE2 & 0.98 & 0.97 \\
\hline
\end{tabular}


Sulaiman \& Muhammad | Islamic Business Ethics Practice among Muslim Entrepreneurs in Kano Metropolis, Nigeria

\begin{tabular}{ccc}
\hline IBE3 & 0.83 & 0.70 \\
IBE4 & 1.00 & 0.99 \\
IBE5 & 0.84 & 0.71 \\
IBE7 & 0.63 & 0.40 \\
LF1 & 0.98 & 0.95 \\
LF2 & 0.92 & 0.84 \\
LF3 & 0.81 & 0.66 \\
LF4 & 0.99 & 0.98 \\
LF5 & 0.98 & 0.95 \\
LF6 & 0.95 & 0.90 \\
LF7 & 0.76 & 0.57 \\
OF1 & 0.93 & 0.87 \\
OF2 & 0.88 & 0.78 \\
OF3 & 0.91 & 0.82 \\
OF4 & 0.99 & 0.98 \\
OF5 & 0.95 & 0.91 \\
IF1 & 0.97 & 0.93 \\
IF2 & 0.97 & 0.93 \\
IF3 & 0.85 & 0.72 \\
IF4 & 0.92 & 0.84 \\
IF5 & 0.84 & 0.71 \\
IF6 & 0.93 & 0.87 \\
IF7 & 0.76 & 0.57 \\
\hline
\end{tabular}

Source: Computed from field Survey Data (2018).

Note: All items have met the recommended value.

According to Figure 3 the CFA results shows that the RMSEA $=0.074, \mathrm{GFI}=$ 0.901. $\mathrm{CFI}=0.968$, and $\mathrm{Chisq} / \mathrm{df}=3.154$. The fitness indexes indicate that the measurement model signifies a satisfactory fit of the data and the result of all the fit indexes yielded adequate fit. In general, the result of the assessment of the measurement model shows solid evidence of unidimensional, construct validity and discriminant validity. Certainly, the model is fit and hence can proceed with further analysis.

Table 6. The Measurement Model Results for Each Construct (After Modification)

\begin{tabular}{|c|c|c|c|c|c|}
\hline Cons & Items & $\begin{array}{l}\text { Factor } \\
\text { loading }\end{array}$ & $\begin{array}{c}\text { Cronbach's } \\
\text { Alpha }\end{array}$ & $\begin{array}{c}\text { C.R. } \\
\text { (Above0.60) }\end{array}$ & $\begin{array}{c}\text { AVE } \\
\text { (Above } 0.50)\end{array}$ \\
\hline
\end{tabular}


Sulaiman \& Muhammad | Islamic Business Ethics Practice among Muslim Entrepreneurs in Kano Metropolis, Nigeria

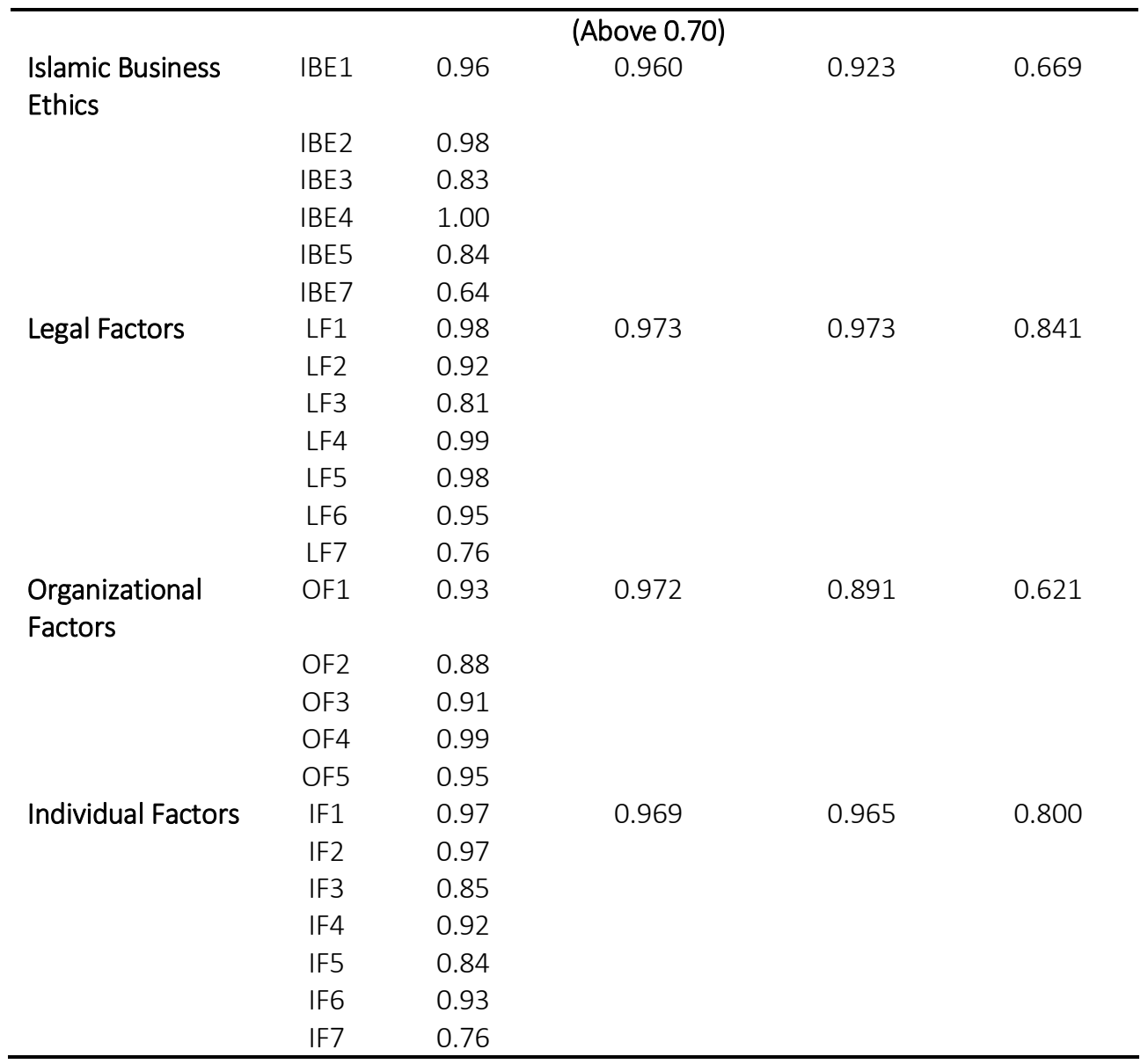

Source: Computed from field Survey Data (2018).

From Table 6 the model has sufficient measurement properties on each single factor model based on its Cronbach's Alpha, Composite Reliability, and Average Variance Extracted. Therefore, with the above result, the model is adequately fit for further analysis. And the missing items were deleted as a result of low factor loading and redundant items are set as pre-parameter estimate as shown in Figure 3.

\subsection{The Assessment of Normality for the Data}

After the fitness indexes have been achieved, there is a need to examine the normality assessment for the data at hand before proceeding to modelling the structural model. Table 9 presents the normality assessment for every item involved in the measurement model (Table 9).

Table 7. The Assessment of Normality Distribution for Items in the Construct

\begin{tabular}{lllllll}
\hline Variable & Min & Max & Skew & C.R. & Kurtosis & C.R. \\
\hline
\end{tabular}


Sulaiman \& Muhammad | Islamic Business Ethics Practice among Muslim Entrepreneurs in Kano Metropolis, Nigeria

\begin{tabular}{|c|c|c|c|c|c|c|}
\hline IF1 & 1 & 5 & -0.994 & -8.086 & 1.255 & 5.104 \\
\hline IF2 & 1 & 5 & -0.982 & -7.987 & 0.835 & 3.396 \\
\hline IF3 & 1 & 5 & -1.083 & -8.81 & 0.902 & 3.668 \\
\hline IF4 & 1 & 5 & -1.059 & -8.616 & 1.16 & 4.716 \\
\hline IF5 & 1 & 5 & -0.945 & -7.684 & 0.57 & 2.318 \\
\hline IF6 & 1 & 5 & -0.903 & -7.344 & 0.656 & 2.666 \\
\hline IF7 & 1 & 5 & -1.107 & -9.006 & 1.112 & 4.523 \\
\hline OF1 & 1 & 5 & -0.938 & -7.627 & 0.901 & 3.663 \\
\hline OF2 & 1 & 5 & -0.863 & -7.021 & 0.715 & 2.908 \\
\hline OF3 & 1 & 5 & -0.904 & -7.352 & 0.838 & 3.409 \\
\hline OF4 & 1 & 5 & -0.592 & -4.812 & 0.173 & 0.705 \\
\hline OF5 & 1 & 5 & -0.672 & -5.467 & 0.365 & 1.485 \\
\hline IBE1 & 1 & 5 & -0.858 & -6.979 & 0.177 & 0.721 \\
\hline IBE2 & 1 & 5 & -1.079 & -8.779 & 0.800 & 3.253 \\
\hline IBE3 & 1 & 5 & -1.019 & -8.288 & 0.699 & 2.844 \\
\hline IBE4 & 1 & 5 & -1.077 & -8.764 & 0.838 & 3.408 \\
\hline IBE5 & 1 & 5 & -1.042 & -8.478 & 0.818 & 3.329 \\
\hline IBE7 & 1 & 5 & -1.283 & -10.438 & 1.416 & 5.76 \\
\hline LF1 & 1 & 5 & -1.186 & -9.651 & 1.339 & 5.445 \\
\hline LF2 & 1 & 5 & -1.285 & -10.454 & 1.448 & 5.889 \\
\hline LF3 & 1 & 5 & -1.127 & -9.168 & 1.055 & 4.291 \\
\hline LF4 & 1 & 5 & -1.234 & -10.037 & 1.545 & 6.284 \\
\hline LF5 & 1 & 5 & -1.201 & -9.771 & 1.394 & 5.671 \\
\hline LF6 & 1 & 5 & -1.24 & -10.083 & 1.368 & 5.564 \\
\hline LF7 & 1 & 5 & -1.156 & -9.401 & 0.972 & 3.953 \\
\hline Multivariate & & & & & 147.081 & 47.958 \\
\hline
\end{tabular}

Source: Computed from field Survey Data (2018).

From Table 7 the result indicates that the Skewness and Kurtosis meet the recommended value of -1 to +1 (Skewness) and -2 to +2 (Kurtosis). This result clearly shows that the data used in this study was normally distributed and also the normality is achieved. With this, the data is suitable to proceed with further analysis that is the Structural Equation Modelling (SEM)/Structural Model. 
Sulaiman \& Muhammad | Islamic Business Ethics Practice among Muslim Entrepreneurs in Kano Metropolis, Nigeria

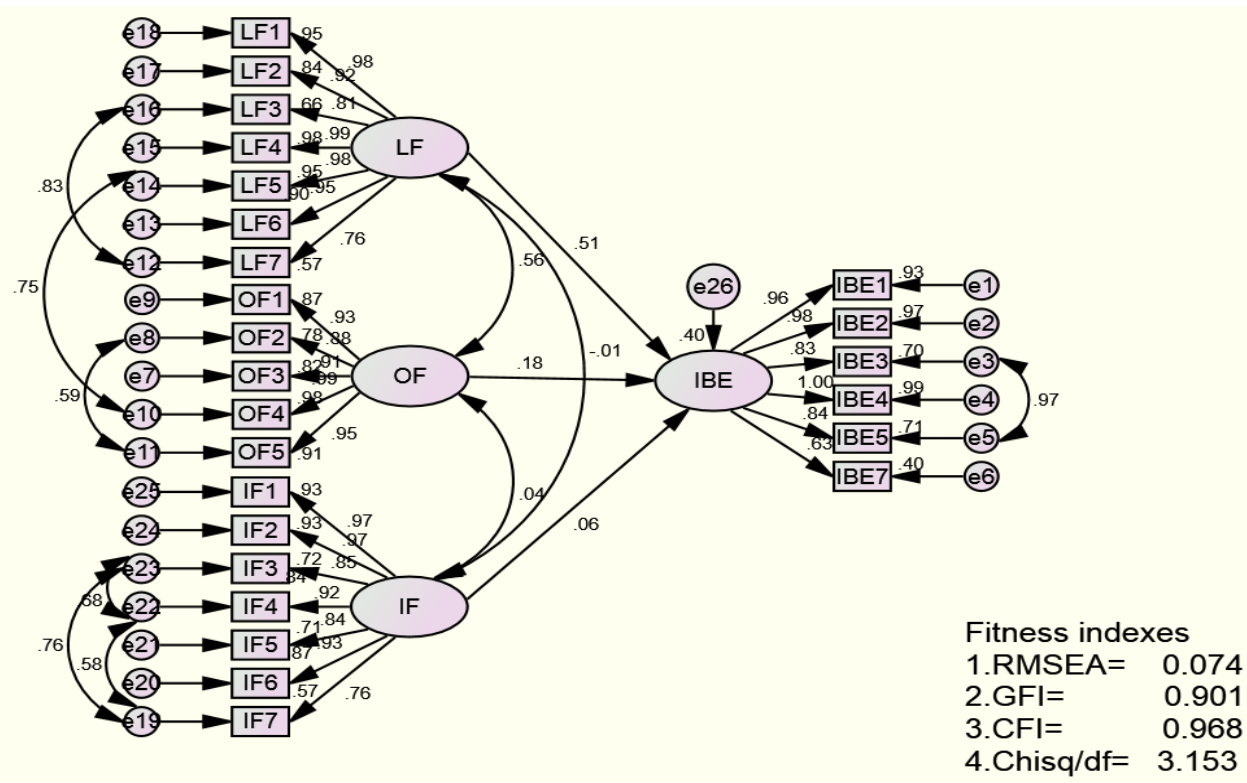

Source: Field Survey Data (2018) and Computed using Amos 22.

Figure 4. The Standardized Estimate for Every Path in the Structural Model.

Table 8. The Standardized Path Coefficients for the Model

\begin{tabular}{lllc}
\hline Dependent Construct & Path & Independent Constructs & Estimate \\
\hline Islamic business ethics & $<--$ & Legal factors & 0.51 \\
Islamic business ethics & $<--$ & Organizational factors & 0.18 \\
Islamic business ethics & $<--$ & Individual Factors & 0.07 \\
\hline
\end{tabular}

Source: Computed from field Survey Data (2018).

The result in Table 8 indicates that when legal factor goes up by 1 standard deviation, Islamic business ethics goes up by 0.51 standard deviation. When organizational factor increases by 1 standard deviation, Islamic business ethics increases by 0.18 standard deviation and also when individual factor goes up by 1 standard deviation, Islamic business ethics goes up by 0.06 standard deviation. The result of Islamic business practice shows that all the seven indicators have enough explanatory power in explaining Islamic business ethics i.e. all factor loadings are greater than 0.6 .

The result in Table 9 indicates that 0.56 is the estimated correlation that exists between legal factors and organizational factors. 0.04 is the estimated correlation between organizational factors and individual factors, while -0.01 is the estimated correlation between individual factors and legal factors. The result in Table 9 shows an acceptable correlation between the constructs which is below 0.85 . 
Sulaiman \& Muhammad | Islamic Business Ethics Practice among Muslim Entrepreneurs in Kano Metropolis, Nigeria

Table 9. The Correlation Estimate for Each Pair of Exogenous Construct

\begin{tabular}{lllc}
\hline Constructs & Path & Constructs & Estimate correlation \\
\hline Legal factor & $<->$ & Organizational factors & 0.56 \\
Organizational factor & $<-->$ & Individual factors & 0.04 \\
Individual factor & $<->$ & Legal factors & -0.01 \\
\hline
\end{tabular}

Source: Computed from field Survey Data (2018).

Table 10. The Squared Multiple Correlation $\left(R^{2}\right)$

\begin{tabular}{lc}
$\begin{array}{l}\text { Variable } \\
\text { Islamic business ethics practice }\end{array}$ & Estimate $\left(R^{2}\right)$ \\
\hline Source: Computed from field Survey Data (2018).
\end{tabular}

The result in Table 10 of the squared multiple correlations indicate that the predictors of the Islamic business ethics practice explain 40 percent of its variance. In other words, the error variance of Islamic business ethics practice is approximately 60 percent of the variance of the Islamic business ethics practice itself.

The regression weight indicates the beta coefficient that measures the effects of every exogenous construct on the endogenous construct.

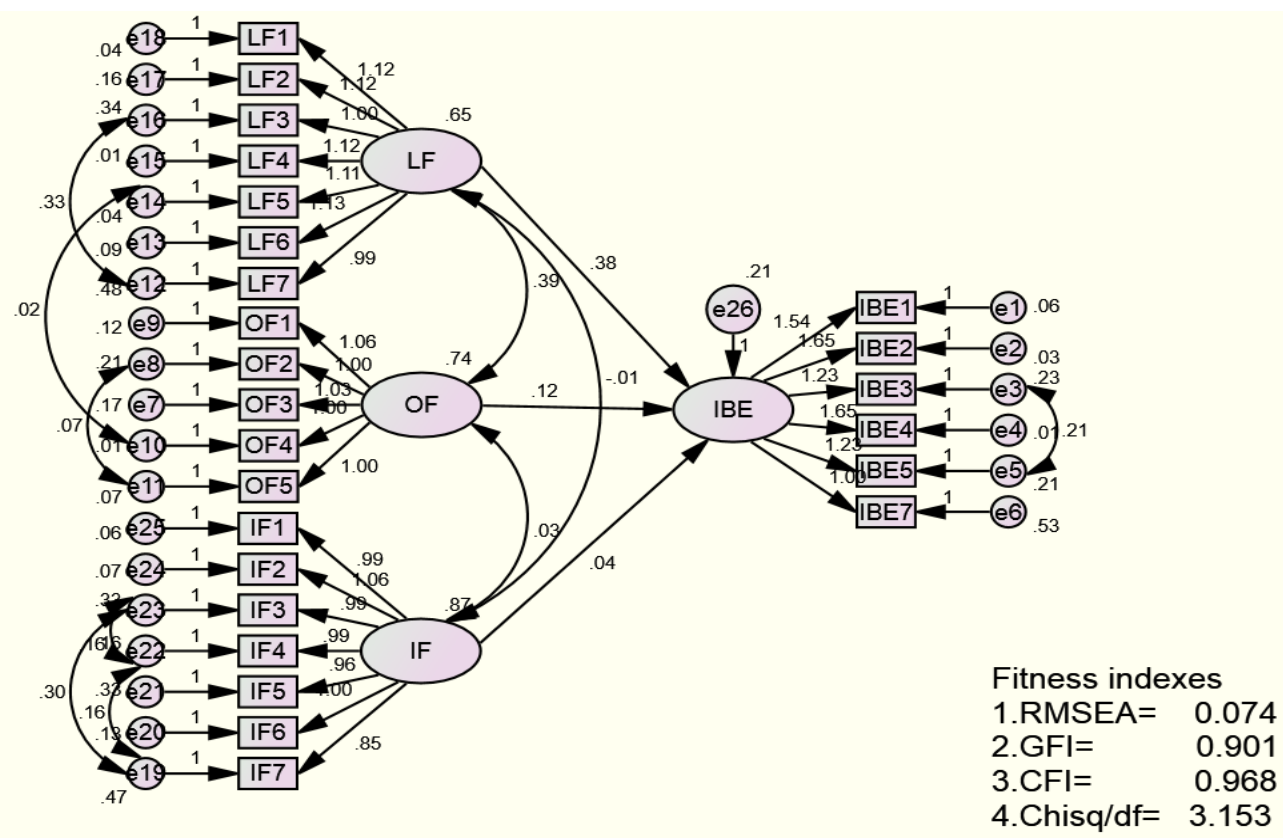

Source: Field Survey Data (2018) and Computed using Amos 22.

Figure 5. (The unstandardized Estimate) Regression Weights for the Model. 
Sulaiman \& Muhammad | Islamic Business Ethics Practice among Muslim Entrepreneurs in Kano Metropolis, Nigeria

Table 11. The Regression Weights for every Path Estimate and it's Significant

\begin{tabular}{lclllll}
\hline & Hypothesized Path & $\begin{array}{c}\text { Beta } \\
\text { Coefficients }\end{array}$ & C.R. & P-Value & Result \\
\hline $\begin{array}{l}\text { Islamic Business } \\
\text { Ethics }\end{array}$ & $<---$ & Legal Factors & 0.376 & 8.56 & $* * *$ & Significant \\
$\begin{array}{l}\text { Islamic Business } \\
\text { Ethics }\end{array}$ & $<--$ & $\begin{array}{l}\text { Organizational } \\
\text { Islamic Business }\end{array}$ & 0.121 & 3.583 & $* * *$ & Significant \\
Ethics & $<---$ & $\begin{array}{l}\text { Factors } \\
\text { Individual Factors }\end{array}$ & 0.041 & 1.628 & 0.104 & $\begin{array}{l}\text { Not } \\
\text { Significant }\end{array}$ \\
\hline
\end{tabular}

Source: Computed from field Survey Data (2018). Notes: ${ }^{* *} p<0.001 ;{ }^{* *} p<0.01 ;{ }^{*} p<0.05$.

In Table XI the path (arrow) and its coefficient are presented which indicate the effects of every exogenous construct on the respective endogenous construct and to achieve the objective of these study three hypotheses are developed, analysed and interpreted below:

\subsection{Testing of Hypothesis}

\subsubsection{Legal Factors and Islamic Business Ethics}

The hypothesis of this study was formulated as: legal factors have no significant influence on Islamic business ethics in Dawanau and Singer markets. The result in Table XI shows that the influence of legal factors on Islamic business ethics is positive (0.376 i.e. $38 \%$ ) and statistically significant $(P<0.001)$, hence this signifies the extent to which adherence to sharia'ah and figh rulings by business entrepreneurs influence their Islamic business ethics practice in Dawanau and Singer market of Kano metropolis, Nigeria Therefore, the alternative hypothesis is accepted, hence legal factor significantly influence Islamic business ethics practice in Dawanau and Singer markets. This finding is consistent with previous results by Imam et al., (2013) which found that legal factors significantly affect Islamic business ethics.

\subsubsection{Organizational Factors and Islamic Business Ethics}

The hypothesis of this study was formulated as: organizational factors have no significant influence on Islamic business ethics practice in Dawanau and Singer markets. The result in Table $\mathrm{XI}$ shows that the influence of organizational factors on Islamic business ethics is positive (0.121) and statistically significant $(P<0.001)$. Therefore, the beta coefficient for the effect of organizational factors on Islamic business ethics was (0.121 i.e. $12 \%)$, and hence this signifies the extent in which organizational leaders i.e. trade union shows commitments toward adherence to Islamic business 
Sulaiman \& Muhammad | Islamic Business Ethics Practice among Muslim Entrepreneurs in Kano Metropolis, Nigeria

ethics in Dawanau and Singer Markets Therefore, the alternative hypothesis was accepted. Hence, organizational factors significantly influence Islamic business ethics practice in Dawanau and Singer markets of Kano metropolis, Nigeria. This finding is consistent with by Husin and kerain (2019), Nizam et al., (2015) as well as Manan et al., (2013) which found that organizational factors significantly affect Islamic business ethics.

\subsubsection{Individual Factors and Islamic Business Ethics}

The hypothesis of this study is formulated as: individual factors have no significant influence on Islamic business ethics in Dawanau and Singer markets. The result in Table XI shows that the influence of individual factor on Islamic business ethics is positive (0.041) and statistically significant $(P<0.104)$. Therefore, the beta coefficient for the effect of individual factor on Islamic business ethics was (0.041 i.e. $4 \%)$, hence the coefficient is very weak and the $p$-value is greater than 0.05 . Therefore, we fail to reject the null hypothesis, hence individual factors do not significantly influence Islamic business ethics practice in Dawanau and Singer markets signifying that pressure from relatives and families, tradition norms and value, life experience, situational factors, as well as stage of moral development less significantly influence the Islamic business ethics of entrepreneurs in Dawanau and singer markets of Kano metropolis Nigeria. This finding tally with characteristics of the respondent educational level were the majority of them have acquired a minimum of islamiyya school education which equip them with skills and knowledge to be more adhered to legal factor/rulings in business than allowing family and relatives pressure to influence their ethical conduct in business. This finding is inconsistent with previous results by Husin and kerain (2019) as well as Nizam et al., (2015), which found that individual factors significantly affect Islamic business ethics.

\section{Conclusions and Conclusion}

\subsection{Conclusions}

The primary aim of this study is to assess the application of Islamic business ethics by Muslim entrepreneurs in Dawanau and Singer Markets. The specific objectives of the study are to assess whether legal factors, organizational factors and Individual factors have significant effects on Islamic business ethics in Dawanau and Singer Markets. To address this, relevant data is collected and analyzed and from the analysis, results are obtained and 
Sulaiman \& Muhammad | Islamic Business Ethics Practice among Muslim Entrepreneurs in Kano Metropolis, Nigeria

discussed. From the discussion of the results, the following conclusions were drawn:

This study concludes that entrepreneurs in Dawanau and Singer market fairly adheres to Islamic business ethics practice, whereas legal and organizational factor significantly influence Islamic business ethics practice in Dawanau and Singer market but individual factor does not significantly influence Islamic business ethics practice of entrepreneurs in Dawanau and Singer market of Kano metropolis.

\subsection{Recommendations}

Based on the findings the following recommendations are suggested. The study recommends the need for Kano State Ministry of Commerce and Industry in collaboration with market organizational leaders to engage in public enlightenment on the importance of business as an act of worship (Ibadat). The study also recommends that organization leaders i.e. Market leaders (trade union leaders) should liaise with Kano state Shariah Commission to set standard for Islamic business ethics whereas Hisbah Board to enforce compliance. The study further suggests that the concept of ethics should be incorporated in teaching and learning curriculum.

\subsection{Recommendation for Further Research}

There is need to replicate this study in different informal sector i.e. markets places within Kano state metropolis and in other jurisdictions with significance population of Muslim entrepreneurs.

There is also need to conduct similar research in formal sector i.e. Islamic financial institutions in Kano metropolis and beyond such as Islamic Commercial Bank, Islamic Insurance (Takaful) company and Islamic micro finance Bank.

Finally, further studies should incorporate additional exogenous, mediating or moderating variables for robustness. 
Sulaiman \& Muhammad | Islamic Business Ethics Practice among Muslim Entrepreneurs in Kano Metropolis, Nigeria

\section{References}

Abdu, A. (2018). The Commander Hisbah Board Commission Dawakin Tofa local government Kano state, Nigeria. Official report.

Ahmad, S. A. (2009). Business ethics in Islam: The glaring gap in practice. International Journal of Islamic and Middle Eastern Finance and Management, 2(4), 278-288.

Bartlett, J. E., Kottrlik, J. W., \& Higgins, C. C. (2001). Determining appropriate sample size in survey research.

Technology, Learning and performance Journal, 19(1), 345-421.

Beekun, R. I. (1996). Islamic business ethics. University of Nevada, USA: The International Institute of Islamic thought.

Beekun, R. I. (2012). Character centred leadership: Muhammad (PBUH) as an ethical role model for CEOs. The Journal of Management Development, 31(10), 1003-1020.

Burji, A. A. (2018). The deputy director government health office; Public health inspection division, ministry of health Kano state. Official report.

Chin, W. (1998). Issues and opinion on Structural Equation Modelling. MIS Quarterly, 22(1), 7-16.

Emmoglu, E. (2011). A structural equation model examining the relationships among Mathematics achievement, attitudes toward statistics, and statistics outcomes, a thesis submitted to the graduate school of social sciences of middle east technical university, Ankara, Turkey.

FAMIS, (2017). Profile of Dawanau International grains market Kano, Friendly Agricultural Market Information Services (FAMIS) a division of friendly agro-allied and logistics company Ltd.

Gefen, D., Straub, D., \& Boudreau, M. (2000). Structural Equation Modelling techniques and regression: guidelines for research practice. Communications of the association for information systems, 7(7), 178.

Hair, J. F., Black, W. C., Babin, B. J., Anderson, R. E., \& Tatham, R. L. (2006). Multivariate data analysis (6ed.). New Jersey: Pearson Prentice Hall.

Hamid, A. W. (1999). Islam the natural way. London: MELS.

Husin, W. N. W., \& Kernain, N. F. Z. (2019). The influence of individual behaviour and organizational commitment towards the enhancement of Islamic work ethics at Royal Malaysian Air Force. Journal of Business Ethics,1(1) 1-11. 
Sulaiman \& Muhammad | Islamic Business Ethics Practice among Muslim Entrepreneurs in Kano Metropolis, Nigeria

Husna, F. S., \& Fuaad, M. (2017). A review of Islamic work ethics and spirituality concepts in service industry Journal of Nusantara Studies, 2(2), 282-294.

Imam, A., Abbasi, A. S., \& Muneer, S. (2013). The impact of Islamic work ethics on employee performance: testing two models of personality $X$ and personality Y. Science International (Lahore), 25(3), 611-617.

Iqbal, M. M., \& Islam, N. B. (2015). Comparative Analysis of business ethics in Islam and Economics Perspective. Journal of Contemporary Issues in Business Research, 4(3), 56-70.

Ismail, A. G. (2006). Paradigm shift from capitalism to Islamic economics. Work Pap. Univ. Kebangs. Malaysia.

Manan, S. K., Kamaluddin, N., \& Puteh Salin, A. S. A. (2013). Islamic work ethics and organizational commitment: Evidence from employees of banking institutions in Malaysia. Pertanika Journal of Social Science and Humanities, 21(4), 1471-1489.

Mohammed, A. (2005). The Relationship between Islamic Rules and Accountants' Ethics. Performance: testing two models of personality $X$ and personality Y. Journal of Business Ethics, 83(2), 147.

Ngurah, G. O. W., Kaderi, S. W., Sufiati, M. P., \& Toha, M. (2014). Measuring Islamic business ethics within Indonesia Islamic banks. Gjat www.gjat.my, 4(5), 345-421.

Nizam, S. B. S., Binti, S. B., Safizal, M. A., \& Osman, A. (2015). The effect of Islamic work ethics on organizational commitment. 7th International Economics \& Business Management Conference, 5th \& 6th October 2015.

Rachels, J., \& Rachels, S. (1993). The elements of moral philosophy. New York: McGraw.

Rahman, A. (1995). Islam: Ideology and the way of life. Kuala Lumpur: A.S. Noordeen.

Umar, S. R. (2018). The commender hisbah board commission fagge local government Kano State, Official report.

Yakasai, U. Z. (2018). The chairman amalgamated traders association zone 2, Singer market, Kano.

Yeboah-Assiamah, E. (2014). Business ethics in Islam: Assessing Traders' Understanding of Islamic Work Ethics; Perspectives of Muslim Market Women in Kumasi Central, Ghana. journal of business and economy, 9(1), 1.

Zainudin, A. (2014). A Handbook on Structural Equation Modelling, Bandar Bangi, Selangor, MPWS Rich Resources. 
Sulaiman \& Muhammad | Islamic Business Ethics Practice among Muslim Entrepreneurs in Kano Metropolis, Nigeria

\section{Appendix}

APPENDEX I: Regression Weights

\begin{tabular}{|c|c|c|c|c|c|c|c|}
\hline \multicolumn{8}{|c|}{ Regression Weights: (Group number 1 - Default model) } \\
\hline & & & Estimate & S.E. & C.R. & $\mathrm{P}$ & Label \\
\hline IBE & $<<--$ & LF & 0.376 & 0.044 & 8.56 & $* * *$ & par_22 \\
\hline IBE & $<---$ & OF & 0.121 & 0.034 & 3.583 & $* * *$ & par_23 \\
\hline IBE & $<---$ & IF & 0.041 & 0.025 & 1.628 & 0.104 & par_34 \\
\hline IBE1 & $<---$ & IBE & 1.54 & 0.098 & 15.71 & $* * *$ & par_1 \\
\hline IBE2 & $<---$ & $\mathrm{IBE}$ & 1.653 & 0.104 & 15.919 & $* * *$ & par_2 \\
\hline IBE3 & $<---$ & $\mathrm{IBE}$ & 1.232 & 0.087 & 14.194 & $* * *$ & par_3 \\
\hline IBE4 & $<---$ & IBE & 1.652 & 0.103 & 16.064 & $* * *$ & par_4 \\
\hline IBE5 & $<---$ & $\mathrm{IBE}$ & 1.234 & 0.086 & 14.329 & $* * *$ & par_5 \\
\hline IBE7 & $<---$ & $\mathrm{IBE}$ & 1.000 & & & & \\
\hline OF3 & $<---$ & OF & 1.029 & 0.037 & 28.178 & $* * *$ & par_6 \\
\hline OF2 & $<---$ & OF & 1.000 & & & & \\
\hline OF1 & $<---$ & OF & 1.057 & 0.035 & 30.144 & $* * *$ & par_7 \\
\hline OF4 & $<---$ & OF & 1.000 & 0.028 & 36.037 & $* * *$ & par_8 \\
\hline OF5 & $<---$ & OF & 0.996 & 0.022 & 46.077 & $* * *$ & par_9 \\
\hline LF7 & $<---$ & LF & 0.985 & 0.024 & 40.948 & $* * *$ & par_10 \\
\hline LF6 & $<---$ & $\mathrm{LF}$ & 1.135 & 0.045 & 24.994 & $* * *$ & par_11 \\
\hline LF5 & $<---$ & $\mathrm{LF}$ & 1.114 & 0.042 & 26.427 & $* * *$ & par_12 \\
\hline LF4 & $<---$ & LF & 1.12 & 0.041 & 27.008 & $* * *$ & par_13 \\
\hline LF3 & $<---$ & LF & 1.000 & & & & \\
\hline LF2 & $<---$ & LF & 1.118 & 0.048 & 23.513 & $* * *$ & par_14 \\
\hline LF1 & $<---$ & $\mathrm{LF}$ & 1.117 & 0.042 & 26.282 & $* * *$ & par_15 \\
\hline IF7 & $<---$ & IF & 0.849 & 0.041 & 20.734 & $* * *$ & par_16 \\
\hline IF6 & $<---$ & IF & 1.000 & & & & \\
\hline IF5 & $<---$ & IF & 0.961 & 0.037 & 26.042 & $* * *$ & par_17 \\
\hline IF4 & $<---$ & IF & 0.994 & 0.03 & 33.471 & $* * *$ & par_18 \\
\hline IF3 & $<---$ & IF & 0.988 & 0.037 & 26.802 & $* * *$ & par_19 \\
\hline IF2 & $<---$ & IF & 1.058 & 0.026 & 41.126 & $* * *$ & par_20 \\
\hline IF1 & $<---$ & IF & 0.993 & 0.024 & 41.29 & $* * *$ & par_21 \\
\hline
\end{tabular}


Sulaiman \& Muhammad | Islamic Business Ethics Practice among Muslim Entrepreneurs in Kano Metropolis, Nigeria

Appendix II: Standardized Regression Weights

\begin{tabular}{|c|c|c|c|}
\hline \multicolumn{4}{|c|}{ Standardized Regression Weights: (Group number 1 - Default model) } \\
\hline & & & Estimate \\
\hline IBE & $<<--$ & LF & 0.515 \\
\hline IBE & $<--$ & OF & 0.175 \\
\hline IBE & $<---$ & IF & 0.065 \\
\hline IBE1 & $<---$ & IBE & 0.963 \\
\hline IBE2 & $<---$ & IBE & 0.982 \\
\hline IBE3 & $<---$ & IBE & 0.834 \\
\hline IBE4 & $<---$ & IBE & 0.997 \\
\hline IBE5 & $<---$ & IBE & 0.845 \\
\hline IBE7 & $<---$ & IBE & 0.63 \\
\hline OF3 & $<---$ & OF & 0.908 \\
\hline OF2 & $<---$ & OF & 0.883 \\
\hline OF1 & $<---$ & OF & 0.932 \\
\hline OF4 & $<---$ & OF & 0.99 \\
\hline OF5 & $<---$ & OF & 0.953 \\
\hline LF7 & $<---$ & LF & 0.756 \\
\hline LF6 & $<---$ & LF & 0.95 \\
\hline LF5 & $<---$ & LF & 0.977 \\
\hline LF4 & $<---$ & LF & 0.991 \\
\hline LF3 & $<---$ & LF & 0.811 \\
\hline LF2 & $<---$ & LF & 0.917 \\
\hline LF1 & $<---$ & LF & 0.977 \\
\hline IF7 & $<---$ & IF & 0.757 \\
\hline IF6 & $<---$ & IF & 0.932 \\
\hline IF5 & $<---$ & IF & 0.84 \\
\hline IF4 & $<---$ & IF & 0.916 \\
\hline IF3 & $<---$ & IF & 0.85 \\
\hline IF2 & $<---$ & IF & 0.965 \\
\hline IF1 & $<---$ & IF & 0.966 \\
\hline
\end{tabular}




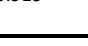


Sulaiman \& Muhammad $\mid$ Islamic Business Ethics Practice among Muslim Entrepreneurs in Kano Metropolis, Nigeria

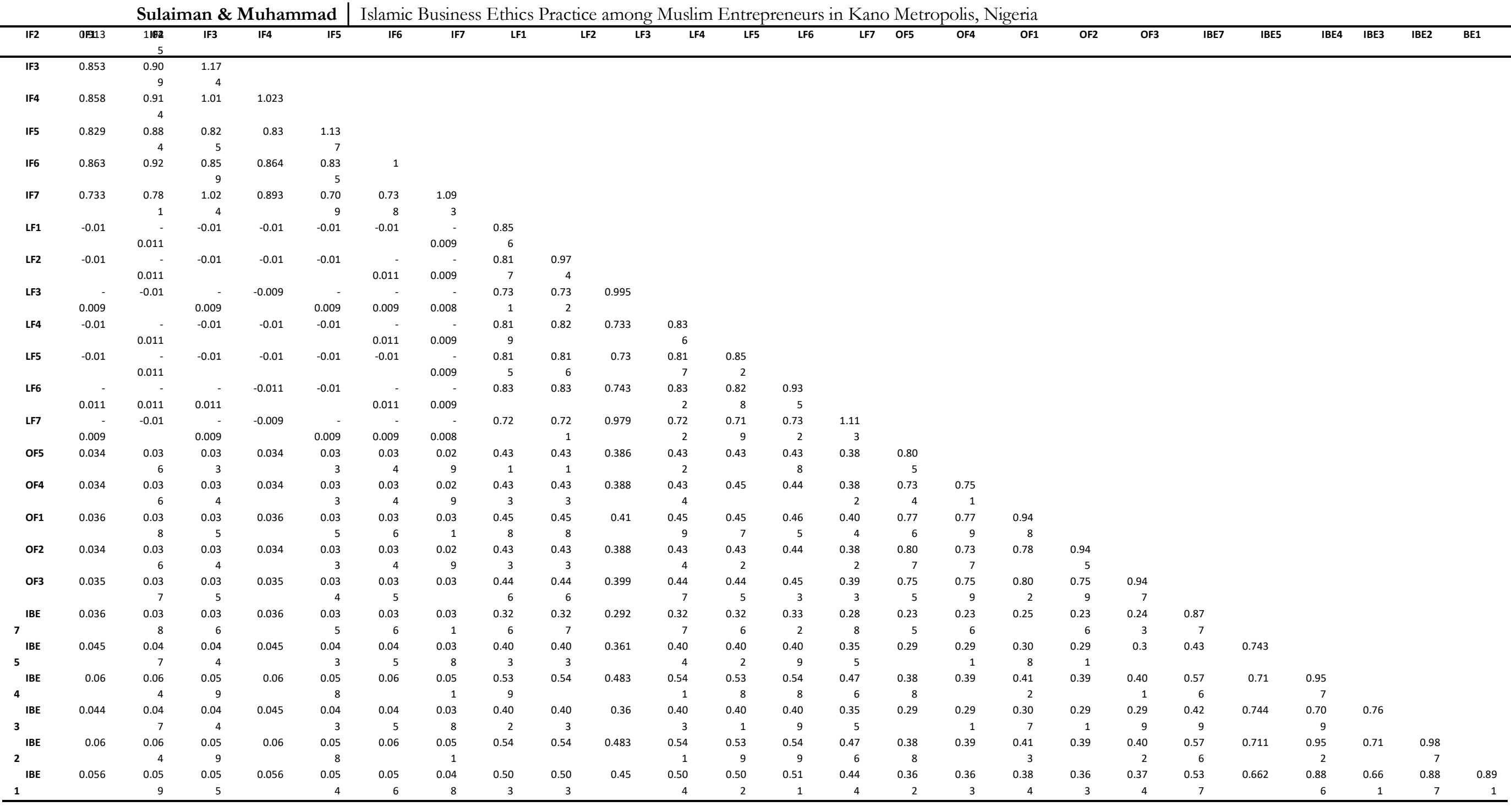




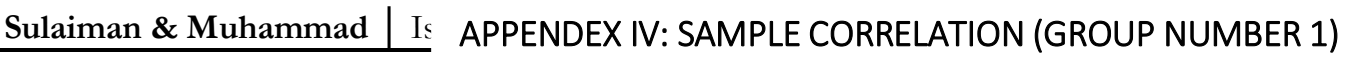

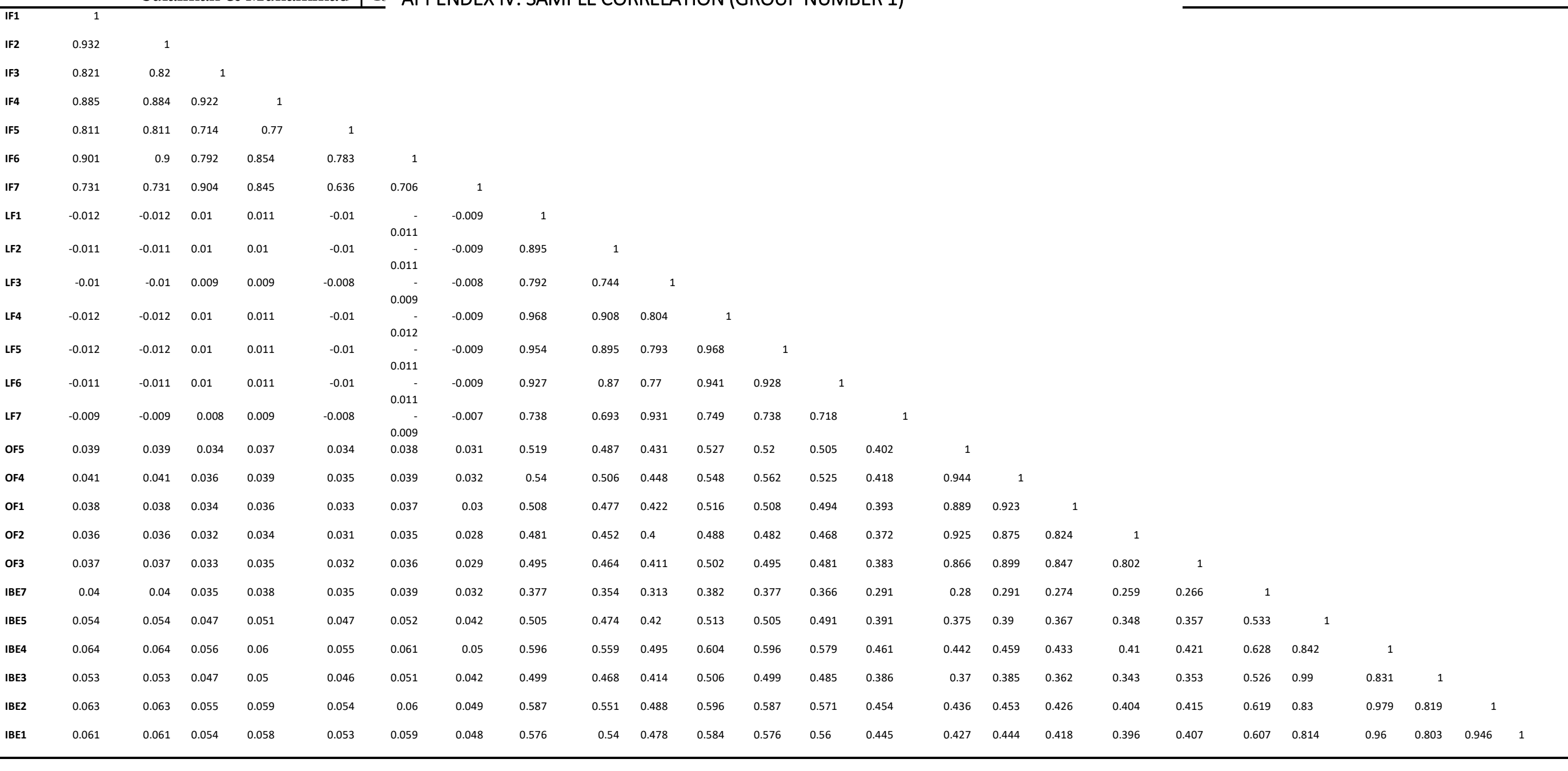


Sulaiman \& Muhammad | Islamic Business Ethics Practice among Muslim Entrepreneurs in Kano Metropolis, Nigeria

This page is intentionally left blank 